\title{
Influence of gender and computer teaching efficacy on computer acceptance among Malaysian student teachers: An extended technology acceptance model
}

\author{
Kung-Teck Wong \\ Sultan Idris Education University, Malaysia \\ Timothy Teo \\ University of Auckland \\ Sharon Russo \\ University of South Australia
}

\begin{abstract}
The purpose of this study is to validate the technology acceptance model (TAM) in an educational context and explore the role of gender and computer teaching efficacy as external variables. From the literature, it appeared that only limited studies had developed models to explain statistically the chain of influence of computer teaching efficacy and gender on the intention of student teachers to use computers. A total of 302 student-teachers completed the questionnaire measuring their responses to computer teaching efficacy (CTE), perceived usefulness (PU), perceived ease of use (PEU), attitude toward computer use (ATCU), and behavioural intention (BI). Structural equation modelling (SEM) was used as the main technique for data analysis. The findings from this study suggest that the model was adequately explained by the data. Overall, the model accounted for $36.8 \%$ of the variance in intention to use computers among student teachers. The results have also provided support for computer teaching efficacy and gender as significant variables in the TAM. Finally, the implications for theory development, practices, and policy making are discussed.
\end{abstract}

\section{Introduction}

Since the mid-1960s, technologies have had revolutionary impacts upon teaching and learning. Technologies have extended the ability of teachers to manage and disseminate knowledge, and provided new opportunities for students to enhance the new knowledge in various aspects (Chai, Koh \& Tsai, 2010; Hong \& Songan, 2011). In this information age, Malaysia, like other developed countries, has a clear vision that information and communications technology (ICT) can transform conventional education systems and bring advantages and benefits to the country as a whole, especially for the younger generation (Wong, Goh, Hanafi \& Osman, 2010). For a while, Malaysian schools have devoted considerable resources to make computer technology an integral part of students' learning experiences, with a view to equipping them with the skills and knowledge necessary to succeed in the 21st century.

The push to incorporate and integrate technology in classroom teaching at all levels became much stronger in the Malaysian education system after the introduction of Smart School. The Smart School is one of the seven flagship applications underlying the 
Multimedia Super Corridor (MSC) which began its operations in 1997. The establishment of the MSC program is to transform Malaysia into a modern state by the year 2020. The objectives of the Smart School are to develop technology savvy individuals and eradicate computer illiteracy. Such strategies began with a sum of 150 million Malaysian Ringgit allocated for 1340 schools to develop their multimedia facilities and computer laboratories, thus paving the way for a revised school curriculum.

The success of integrating technology in teaching and learning depends strongly upon the engagement of teachers. Having teachers who are competent in using and managing educational technology is important. Teachers are expected to be on the frontline of this educational reform. As such, the groundwork must be laid at student teacher's level. There is a growing corpus of research suggesting the importance of understanding the levels of technology acceptance among student teachers, as it is the key factor associated with classroom use of technology in the future. It is important to ensure that the new upcoming teachers are comfortable and capable in integrating ICT into our students' education.

The Malaysian Government has also injected millions of Ringgit to equip student teachers with a range of computer skills and knowledge, and simultaneously ensure a higher level of technology integration in teaching and learning. They must be well trained in order to integrate computers into their curricula. Today, numerous teacher education providers in Malaysia have made extensive efforts to implement effective and meaningful use of technology in their teacher education programs (Wong et al., 2010).

\section{Focus of the present study}

While Malaysian stakeholders in education expect a high level of technology adoption in the classrooms, there is also a growing concern that many Malaysian student teachers lack the experience or skills to integrate this new technology in teaching and learning (Wong et al., 2010). Researchers from other parts of the world and from Malaysia have provided evidence to support the crucial role that student teachers play in the process of implementing computers in the classrooms (Almekhlafi \& Almeqdadi, 2010; Rasimah, Ahmad \& Zaman, 2011; Wong \& Teo, 2009), implying that an understanding of how student teachers react is essential for any successful implementation of computer use in the classroom. This will also in turn, provide insight into issues relating to the acceptance of technology among student teachers. The need to explore factors influencing Malaysian student teachers' acceptance of computing has become a crucial issue and it needs to be addressed urgently.

In this study, the theoretical grounding for exploring factors influencing student teachers' use of computers is drawn from the technology acceptance model (TAM) (Davis, 1989) (Figure 1). The TAM posits that perceived usefulness and perceived ease of use are the two key fundamental predictors of user acceptance of a system. Perceived usefulness is defined as the degree to which a person believes that using a particular technology will enhance his or her job performance. Perceived ease of use is considered the extent to which a person believes that using the system will be free of effort (Davis, 1989). This means that both perceived usefulness and perceived ease of use are the determinants that extrinsically motivate student teachers to use technology. Since its inception, many studies have expanded this model to include study of a broad range of end users (Teo \& Noyes, 2011; Venkatesh \& Davis, 2000). King \& He (2006) 
conducted a meta-analysis on TAM and found 88 published studies supporting the validation of the TAM.

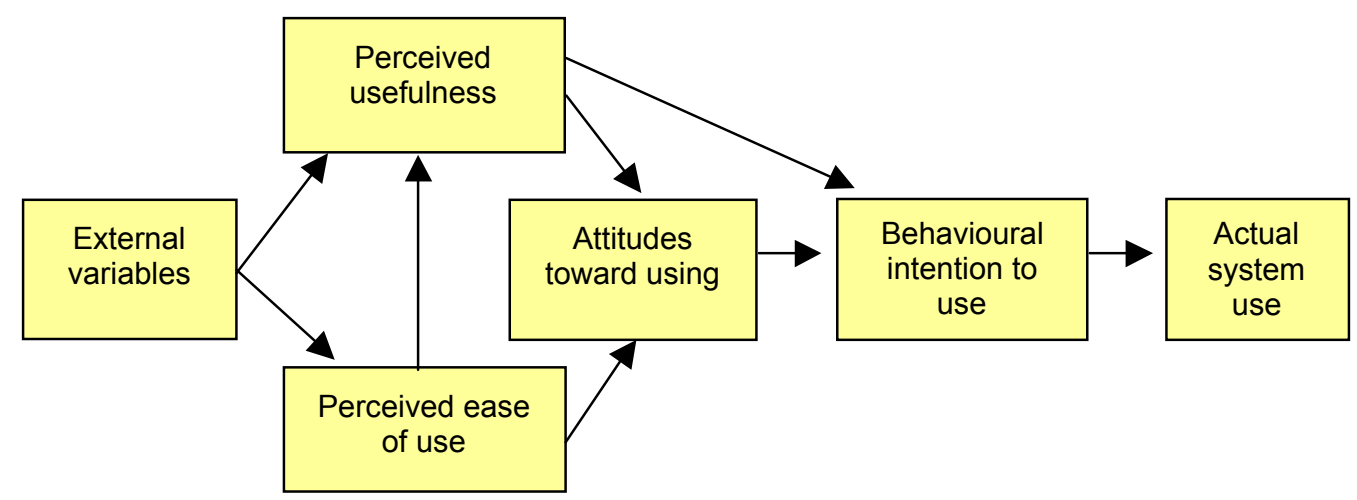

Figure 1: Technology acceptance model (TAM)

Despite the accolades given to the TAM for its predictive ability, it is crucial to explore further into the contribution of external variables. Indeed, many recent studies have found the effects of the external variables, which include perceived enjoyment (Teo \& Noyes, 2011), facilitating conditions (Terzis \& Economides, 2011), social influence (Moran, Hawkes \& El Gayar, 2010; Terzis \& Economides, 2011), self-efficacy (Ahmad, Basha, Marzuki, Hisham \& Sahari, 2010; Chen, 2010; Moran et al., 2010; Terzis \& Economides, 2011), as extension variables toward the TAM to explain the intention to use technology. Thus, in this research, the researchers believe that using generic TAM might result in inconsistent outcomes. Furthermore, Venkatesh and Morris (2000) suggested that self-efficacy or computer self-efficacy should be included as a determinant to explain the acceptance behaviours of its users.

From the literature, it appeared that some technology acceptance studies have highlighted the importance of computer self-efficacy, in explaining the chain of influence toward the attitude and behavioural intention among Malaysian student teachers (Ahmad et al., 2010; Teo, 2009a). However, none was directly related to teachers' computer teaching efficacy. Thus, those findings are unable to contribute much in the field of educational technology in the Malaysian context. This study has gone a step further to address a specific pedagogical self-efficacy issue; that is, the influence of student teachers' computer teaching efficacy on their intention to use computers. Computer teaching efficacy is referred to as an evaluation of their capability to teach with computers and their personal belief in using computers as an effective teaching tool to improve students' performance in learning.

Examining student teachers' intention to use technology is yet another area in which gender may manifest itself. However, generally it has been neglected in technology acceptance studies (Gefen \& Straub, 1997). Having that, this study further understands the moderating effect of gender on the relationship between the determinants and behavioural intention. Over decades, although many studies have investigated the role of gender in computer related attitudes and its use, very few studies have incorporated gender as moderator in assessing the correlations between computer teaching efficacy, perceived ease of use, and perceived usefulness towards the intention of computer use in an educational context. Chu (2010) revealed that gender differences in the use of the 
technology should be carefully examined, rather than merely demonstrating differences. Understanding gender differences in the strength of the path coefficients could bring further insight into stereotypical beliefs regarding gender issues especially in developing countries. Furthermore, the magnitude of gender differences may vary across cultures (Gefen \& Straub, 1997). Premised on the above mentioned situation, the present study was conducted to explore the applicability of the TAM in an educational context with gender and computer teaching efficacy as external variables in the TAM.

\section{Theoretical framework and hypotheses}

With the ongoing development of educational technologies, various theoretical models have emerged to explore and explain factors that influence users' acceptance, rejection or continuing use of new technology (Ajzen, 1985; Ajzen \& Fishbein, 1980; Venkatesh \& Davis, 2000; Venkatesh, Morris, Davis, \& Davis, 2003). Rooted in the work of Ajzen and Fishbein's model, Theory of Reasoned Action (TRA), Davis (1989) introduced and developed the Technology Acceptance Model (TAM) and provided a theoretical context that explained the relationship of attitude-intention-behaviour (Figure 1). Based on the TAM, perceived usefulness and perceived ease of use are hypothesised to be fundamental determinants of user acceptance.

Many reports provide evidence of the impact of perceived usefulness and perceived ease of use on attitude toward usage and behavioural intention (Rasimah et al., 2011; Teo, 2011; Wong \& Teo, 2009; Sumak, Hericko, Pusnik \& Polancic, 2011). Wong and Teo found that those variables were significant determinants of the attitude and intention to use technology among student teachers. Furthermore, perceived usefulness had a direct impact on intention to use, while perceived ease of use influenced intention to use indirectly through attitude.

Sumak et al. (2011) revealed that perceived usefulness and perceived ease of use were factors that directly affected students' attitude, and perceived usefulness was the strongest and most significant determinant of students' attitude toward using technology in learning. This finding was in congruence with that of Davis (1989), and Davis, Bagozzi and Warshaw (1989). Davis et al. (1989) also found that perceived ease of use would have only one direction towards perceived usefulness and this has been confirmed by recent studies (Shroff, Deneen \& Ng, 2011; Teo, 2011; Sumak et al., 2011). The following hypotheses were generated:

H1a Perceived usefulness will significantly and positively influence student teachers' attitude toward computer use.

H1b Perceived usefulness will significantly and positively influence student teachers' behavioural intention to use computer.

H2a Perceived ease of use will significantly and positively influence student teachers' perceived usefulness.

$\mathrm{H} 2 \mathrm{~b}$ Perceived ease of use will significantly and positively influence student teachers' attitude toward computer use.

H3 Attitude toward computer use will significantly and positively influence student teachers' behavioural intention to use computers. 


\section{External variables}

\section{Computer teaching efficacy}

Computer teaching efficacy refers to student teachers' evaluation of their capability to teach with computers (self-efficacy belief), and their personal beliefs in using computers as an effective teaching method to improve students' performance in learning (outcomes expectation). Computer teaching efficacy is drawn from Bandura's self-efficacy theory (Bandura, 1977), which advocated a belief in one's capability for performing a specific task. Bandura's theory states that people will be motivated to perform an action if they are confident that they can perform that action successfully, and believe that the action will have a favourable result (outcome expectation).

There is a growing corpus of studies which suggest that a causal link exists between self-efficacy and perceived usefulness (Ahmad et al., 2010; Chen, 2010; Compeau \& Higgins, 1995; Hayes, 2007; Venkatesh, 2000; Wong et al., 2010; Wozney, Venkatesh \& Abrami, 2006). Chen (2010) found that pre-service teachers' self-efficacy of teaching with technology had the strongest influence on technology use, which was mediated by their belief about the usefulness of technology in teaching and learning with technology. This was coherent with Wong et al. (2010) who found that that self-efficacy was a good predictor for computer use among mathematics, science and English language teachers in Malaysia. Wozney et al. (2006) found that teachers' expectancy of success and prediction of positive outcomes of their actions were the vital determinants for their levels of computer use. Venkatesh (2000) and Hayes (2007) noted that self-efficacy had a direct effect on perceived ease of use. Hayes conducted a study in Australian classrooms and revealed that the more confident an instructor was in his or her abilities to use information systems, the more the instructor believed that the system could be used easily. This finding is consistent with Ahmad et al. (2010) who found that computer self-efficacy was an important determinant in affecting faculty members' use of computer technology.

H4a Computer teaching efficacy will significantly and positively influence student teachers' perceived usefulness.

$\mathrm{H} 4 \mathrm{~b}$ Computer teaching efficacy will significantly and positively influence student teachers' perceived ease of use.

$\mathrm{H} 4 \mathrm{c}$ Computer teaching efficacy will significantly and positively influence studentteachers' attitude toward computer use.

\section{Gender}

The debate over the gender gap that started in the 1980s still persists in the new millennium. Recently, many researchers have revisited the issue of its role in different perspectives in the educational technology context. Gender differences in terms of teacher belief, teacher self-efficacy, and attitude towards computers is an important research field (Sang, Valcke, van Braak \& Tondeur, 2010). Sieverding and Koch (2009) investigated gender differences in computer self-efficacy and revealed that women have lower computer self-efficacy than men. This finding was in line with the findings of Koch, Muller and Sieverding (2008) and Ong and Lai (2006).

Gefen and Straub (1997), Venkatesh and Morris (2000), Venkatesh et al. (2003), Wang and Shih (2009) and Wang and Wang (2010) investigated the effect of gender on 
technology acceptance and determined that gender significantly moderated the effects of perceived usefulness and perceived ease of use towards behavioural intention. Studies found that men were more task-oriented and affected by perceived usefulness, while women were more affected by perceived ease of use which was related to their self-efficacy (Venkatesh, et al., 2003; Wang \& Shih, 2009). The following hypotheses were generated, giving the research model in Figure 2:

H5a Computer teaching efficacy influences perceived usefulness more strongly for men than for women.

$\mathrm{H} 5 \mathrm{~b}$ Computer teaching efficacy influences perceived ease of use more strongly for men than for women.

$\mathrm{H} 5 \mathrm{c}$ Computer teaching efficacy influences attitude toward computer use more strongly for men than for women.

H6a Perceived usefulness influences attitude toward computer use more strongly for men than for women.

H6b Perceived usefulness influences behavioural intention more strongly for men than for women.

H7a Perceived ease of use influences attitude toward computer use more strongly for women than for men.

H8 Attitude toward computer use influences behavioural intention more strongly for men than for women.



Figure 2: Research model

\section{Research method}

\section{Research design}

Data were gathered by means of a survey questionnaire, containing questions focusing on demographics and scales measuring the variables in the research model (Figure 2): computer teaching efficacy, perceived usefulness, perceived ease of use, attitude 
toward computer use, and behavioural intention. Methodologically, structural equation modelling (SEM) has been used to assess the validity of the TAM in the Malaysian student teachers' context and explore the impacts of extended variables, gender and computer teaching self-efficacy, on the suggested model. From the literature, SEM is widely used to predict or explain the determinants of a user's intention or use of technology in an educational setting (Terzis \& Economides, 2011; Sumak et al., 2011). The AMOS statistics software program was employed in this study.

\section{Participants and data collection}

Participants were student teachers from the Sultan Idris Education University (UPSI) in Malaysia. A total of 302 respondents, representing a response rate of $86.4 \%$, completed the survey questionnaire. Some questionnaires were discarded due to being only partially complete. Among these participants, $64.2 \%$ (194) were female, and the mean age of all participants was 22.9 years $(S D=2.12)$. Most of them frequently accessed a computer at home $(77.33 \%)$. Participation was wholly voluntary and no course credits were given. All participants were briefed on the purpose of the study and told of their right to withdraw during or after the data collection. The questionnaires were distributed and collected during the final hour on the last day of lectures. Participants were given about 20 minutes to complete the questionnaire.

\section{Instruments}

A self-report questionnaire was developed for the survey. The survey measured five constructs and a total of 13 items on computer teaching efficacy, perceived usefulness, perceived ease of use, attitude toward computer use and behavioural intention. Respondents were asked to indicate the items on a four-point Likert scale ranging from strongly disagree (1), slightly disagree (2), slightly agree (3), to strongly agree (4). Each item was coded so that the higher the score, the more positive the level of entire constructs would be. These items were adapted from various published sources and were found to be reliable and valid (Compeau \& Higgins, 1995; Davis, 1989; Gibson \& Dembo, 1984; Riggs \& Enochs, 1990; Thompson, Higgins \& Howell, 1991; Venkatesh et al., 2003). For example, the items measuring perceived usefulness, perceived ease of use, and attitude toward computer use were employed in Teo (2009) with good coefficients of $.96, .95$, and .93 respectively. Furthermore, the questionnaire was piloted on 51 student teachers and the results revealed acceptable reliability of all constructs. The Cronbach alphas were .89 for perceived usefulness; .77 for computer teaching efficacy; .96 for perceived ease of use; .66 for attitude toward computer use, and .78 for behavioural intention. All items were presented in English. The 13 items in this study are listed in the Appendix.

\section{Results}

Analysis of the data in this study was conducted in two phases. The first phase examined the descriptive statistics and assessed the reliability and validity of the measurement items. This was to ensure that the data would be adequate for structural equation modelling. For the second phase, assessments on the contributions and significance of the predictors towards computer use among student teachers were performed. 


\section{Descriptive statistics}

A descriptive analysis was carried out on computer teaching efficacy, perceived usefulness, perceived ease of use, attitude toward computer use and behavioural intention, and their mean and standard deviation are shown in Table 1. All means scores are above the midpoint of 2.5, ranging from 2.5 to 3.1. This indicates an overall positive response to the constructs in the study. The standard deviation (SD) values suggest a narrow spread around the mean. Univariate normality was assessed through the inspection of the skewness and kurtosis, with values less than 3.0 and 10 respectively, indicative of acceptable normality (Kline, 2005). The skewness and kurtosis indices for all constructs are acceptable and internal reliability is also adequate. The data in this study are regarded as normal for the purpose of structural equation modelling.

Table 1: Descriptive statistics of the study constructs

\begin{tabular}{|c|c|c|c|c|}
\hline Construct & Mean & Std dev & Skewness & Kurtosis \\
\hline CTE & 2.53 & .99 & .083 & -1.14 \\
\hline PU & 2.54 & .93 & -.021 & .28 \\
\hline PEU & 3.06 & .90 & -.75 & -.53 \\
\hline ATCU & 3.11 & .81 & -.32 & -1.04 \\
\hline BI & 2.86 & .93 & -.11 & -1.37 \\
\hline
\end{tabular}

\section{Evaluation of the measurement model}

A confirmatory factor analysis (CFA) was conducted to test the measurement model. Table 2 shows the result of the measurement model. The factor loadings of the individual items in the five constructs are all above .50. Together, the principal component analysis showed that these five constructs in the proposed model explained $87.87 \%$ of the total variance. All standardised regression weights are above .70 and range from .786 to .970 . Furthermore, the multiple square correlation $\left(\mathrm{R}^{2}\right)$ of all items ranged from .640 to .940 , suggesting that these items were explained by their predictors at a range from $64 \%$ to $94 \%$. A value of .50 or greater is considered appropriate (Hair, Black, Babin \& Anderson, 2010).

The test of convergent validity was conducted using average variance extracted (AVE) and composite reliability measurement. According to Hair, Black, Babin and Anderson (2010), in order to ensure the AVEs index are adequate for testing structural equation modelling, they should equal or exceed 0.50. Table 2 shows that the AVE for each measure is above 0.50 . This means that more than one-half of the variances observed in the items were accounted for by their hypothesised factors. The composite reliability (CR) of each construct was assessed using Cronbach's alpha. The composite reliability for all the factors in the measurement model ranges from .85 to .97 and it exceeds the recommended threshold value (Hair et al., 2010).

Table 3 shows the results of discriminant validity of the measured items. Discriminant validity is present when the variance shared between a construct and any other construct in the model is less than the variance that construct shares with its indicators. If the square roots of the AVEs are greater than the off-diagonal elements in the corresponding rows and columns, it shows that the construct has stronger correlation with its indicators than with the other constructs in the model (Teo, 2009). From Table 3 , the values in the matrix diagonals, representing the square roots of the AVEs, are 
greater than the off-diagonal elements in their corresponding rows and columns, suggesting that discriminant validity was present in the proposed research model.

Table 2: Results of the measurement model

\begin{tabular}{|c|c|c|c|c|c|c|c|}
\hline $\begin{array}{c}\text { Latent } \\
\text { variable }\end{array}$ & Item & $\begin{array}{c}\text { Factor } \\
\text { loading } \\
(>.60)^{*}\end{array}$ & SE & $\begin{array}{l}\text { t-value } \\
\text { (a) }\end{array}$ & $\mathrm{R}^{2}$ & $\begin{array}{c}\text { Average } \\
\text { variance extracted } \\
(\geq .50)^{*}(b) \\
\end{array}$ & $\begin{array}{l}\text { Composite } \\
\text { reliability(c) } \\
(\geq .50)^{*}\end{array}$ \\
\hline \multirow[t]{3}{*}{ CTE } & CTE1 & .873 & .919 & 22.671 & .844 & \multirow[t]{3}{*}{.72} & \multirow[t]{3}{*}{.91} \\
\hline & CTE2 & .850 & .887 & - & .788 & & \\
\hline & CTE3 & .830 & .853 & 20.044 & .727 & & \\
\hline \multirow[t]{3}{*}{ PU } & PU1 & .768 & .932 & 17.631 & .869 & \multirow[t]{3}{*}{.58} & \multirow[t]{3}{*}{.87} \\
\hline & PU2 & .662 & .800 & 15.070 & .640 & & \\
\hline & PU3 & .838 & .786 & - & .618 & & \\
\hline \multirow[t]{3}{*}{ PEU } & PEU1 & .891 & .970 & 37.198 & .940 & \multirow[t]{3}{*}{.80} & \multirow[t]{3}{*}{.97} \\
\hline & PEU2 & .892 & .939 & 32.731 & .882 & & \\
\hline & PEU3 & .907 & .940 & - & .884 & & \\
\hline \multirow[t]{2}{*}{ ATCU } & ATCU1 & .838 & .898 & - & .807 & \multirow[t]{2}{*}{.72} & \multirow[t]{2}{*}{.89} \\
\hline & ATCU2 & .854 & .819 & 14.136 & .671 & & \\
\hline \multirow[t]{2}{*}{ BI } & BI1 & .890 & .930 & - & .748 & \multirow[t]{2}{*}{.78} & \multirow[t]{2}{*}{.85} \\
\hline & BI2 & .877 & .865 & 14.775 & .866 & & \\
\hline
\end{tabular}

a. $t$-value(critical ratio) shows whether the parameter is significant at the .05 level.

b. AVE: Average variance extracted $=\left[\operatorname{sigma}\left(\lambda^{2}\right)\right] / \mathrm{n}$

c. Composite reliability $=[\operatorname{sigma}(\lambda)]^{2} /[\operatorname{sigma}(\lambda)]^{2}+\operatorname{sigma}(\lambda)\left[1-\operatorname{sigma}\left(\lambda^{2}\right)\right]$

* Indicates an acceptance level or validity.

- This value was fixed at 1.00 for model identification purposes

SE: Standard estimate

Table 3: Discriminant validity for measurement model

\begin{tabular}{|c|c|c|c|c|c|}
\hline & CTE & PU & PEU & ATCU & BI \\
\hline CTE & $(.85)$ & & & & \\
\hline PU & $.52^{\star *}$ & $(.76)$ & & & \\
\hline PEU & $.47^{\star *}$ & $.65^{\star *}$ & $(.90)$ & & \\
\hline ATCU & $.57^{\star}$ & $.51^{*}$ & $.35^{* *}$ & $(.85)$ & \\
\hline BI & $.41^{\star *}$ & $.50^{*}$ & $.41^{* *}$ & $.42^{* *}$ & $(.88)$ \\
\hline
\end{tabular}

Notes: Diagonal in parentheses: square root of average variance extracted from observed variables (items); Off-diagonal: correlations between constructs. ${ }^{*} p<.05 ;{ }^{* *} p<.01$

The five absolute fit indices: ratio of $\chi^{2}$ to its degree of freedom $\left(\chi^{2} / d f\right)$, Goodness of Fit (GFI), Comparative Fit Index (CFI), Tucker-Lewis Index (TLI), and Standardised Root Mean Square Error of Approximation (RMSEA) were employed in order to check the model fit of the measurement model. Absolute fit indices measure how well the proposed model reproduces the observed data. According to Hair et al. (2010), the value of GFI and CFI should be more than 0.95 and that of the RMSEA smaller than 0.05 to be considered a good fit. For $\chi^{2} / d f$ (ratio of $\chi^{2}$ to its degrees of freedom), the value below 3 is considered acceptable. Finally, the TLI value should be greater than 0.90. As shown in Table 4, all values are above the recommended thresholds for acceptable model fit and it confirms that the measurement model has exhibited a good fit. 
Table 4: Goodness of fit indices for the measurement model

\begin{tabular}{|l|c|c|}
\multicolumn{1}{|c|}{ Fit indices } & Values & \multicolumn{1}{c|}{ Criteria(a) } \\
\hline$\chi^{2}$ statistic & $138.31^{* *}$ & $\begin{array}{c}\text { Insignificant, but significant } \\
p \text {-value can be expected. }\end{array}$ \\
\hline $\begin{array}{l}\chi^{2} / d f\left(\text { ratio of } \chi^{2} \text { to its }\right. \\
\text { degrees of freedom) }\end{array}$ & 2.51 & $<3$ \\
\hline RMSEA & 0.07 & $<0.08$ \\
\hline GFI & 0.93 & $\geq 0.90$ \\
\hline CFI & 0.98 & $\geq 0.90$ \\
\hline TLI & 0.97 & $\geq 0.90$ \\
\hline
\end{tabular}

a. References are taken from Hair et al.(2010), Kline (2005) and McDonald and Ho (2002).

${ }^{* *} p<.01$

\section{Hypotheses testing}

Figure 3 shows the parameter estimates for the hypothesised model. Hypotheses H1a, $\mathrm{H} 1 \mathrm{~b}, \mathrm{H} 2 \mathrm{a}, \mathrm{H} 2 \mathrm{~b}, \mathrm{H} 3, \mathrm{H} 4 \mathrm{a}, \mathrm{H} 4 \mathrm{~b}$ and $\mathrm{H} 4 \mathrm{c}$ were supported by the data. The exogenous variable shows that computer teaching efficacy was a significant influence on perceived usefulness $(\beta=.22, \mathrm{p}<.00)$, perceived ease of use $(\beta=.48, \mathrm{p}<.00)$ and attitude toward computer use $(\beta=.38, p<.00)$. Perceived usefulness was a significant influence on attitude toward computer use $(\beta=.47, \mathrm{p}<.00)$ and behavioural intention BI $(\beta=.52$, $\mathrm{p}<.00)$. Perceived ease of use was a significant influence on perceived usefulness $(\beta=.50, \mathrm{p}<.00)$ and attitude toward computer use $(\beta=-.14, \mathrm{p}<.00)$. Finally, behavioural intention was found to be influenced by attitude toward computer use $(\beta=.23, \mathrm{p}<.01)$.

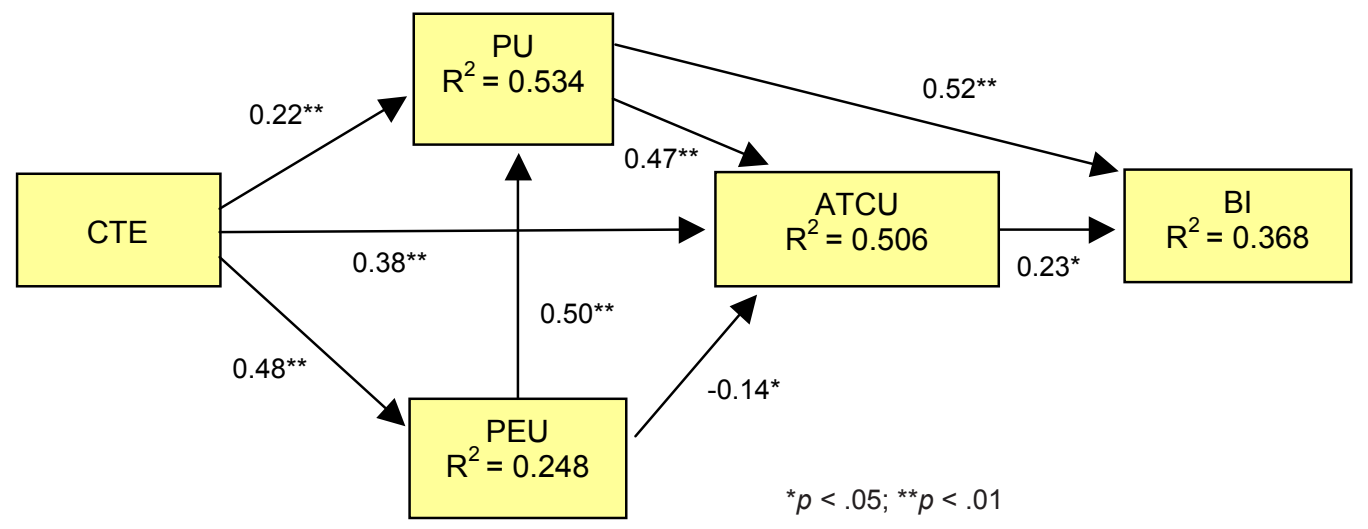

Figure 3: Standardised path coefficients for all respondents

Attitude toward computer use was found to be significantly determined by computer teaching efficacy, perceived usefulness and perceived ease of use, resulting in an $R^{2}$ of 0.506. In other words, computer teaching efficacy, perceived usefulness and perceived ease of use have explained $50.6 \%$ of the variance in attitude toward computer use. Perceived usefulness was significantly determined by computer teaching efficacy, and perceived ease of use and the percent of variance explained was $53.4 \%\left(R^{2}=0.534\right)$. Perceived ease of use was significantly determined by computer teaching efficacy, resulting in an $\mathrm{R}^{2}=.248$. Altogether, the model accounted for $36.8 \%$ of the variance in behavioural intention. 


\section{Assessment of total, direct, and indirect effects}

To test and estimate confidence intervals for the indirect effect, a bootstrapping test was conducted. Table 5 shows the standardised total effects, direct and indirect effects associated with each of the endogenous and exogenous variables toward intention for computer use. According to MacKinnon (2008), standardised path coefficients with values near to 1 are considered to be large values impact. The most dominant determinant of behavioural intention is perceived usefulness, with a total effect of 0.629. This is followed by computer teaching efficacy, perceived ease of use, and attitude toward computer use with a total effect of $0.361,0.281$, and 0.23 respectively. Together, these four determinants account for approximately $36.8 \%$ of the variance in behavioural intention in computer use. Additionally, computer teaching efficacy performed as a good determinant for all endogenous variables in the model.

Table 5: Direct, indirect and total effects of the research model

\begin{tabular}{|c|c|c|c|c|c|}
\hline \multirow{2}{*}{ Outcome } & \multirow{2}{*}{ Determinant } & \multicolumn{4}{|c|}{ Standardised estimates } \\
\hline & & $\mathrm{R}^{2}$ & Direct & Indirect & Total(a) \\
\hline \multirow[t]{2}{*}{ PU } & CTE & \multirow[t]{2}{*}{0.534} & 0.222 & 0.238 & $0.460^{* *}$ \\
\hline & PEU & & 0.500 & - & $0.500^{* *}$ \\
\hline PEU & CTE & 0.248 & 0.476 & - & $0.476^{* *}$ \\
\hline \multirow[t]{3}{*}{ ATCU } & CTE & \multirow[t]{3}{*}{0.506} & 0.383 & 0.147 & $0.530^{*}$ \\
\hline & PEU & & -.149 & 0.237 & $0.08^{*}$ \\
\hline & PU & & 0.473 & - & $0.473^{*}$ \\
\hline \multirow[t]{4}{*}{ BI } & CTE & \multirow[t]{4}{*}{0.368} & - & 0.361 & $0.361^{* *}$ \\
\hline & PEU & & - & 0.281 & $0.281^{* *}$ \\
\hline & PU & & 0.520 & 0.109 & $0.629^{* *}$ \\
\hline & ATCU & & 0.230 & - & $0.230^{*}$ \\
\hline
\end{tabular}

a. 200 samples bootstrapping test with $95 \%$ of confidence interval (CI)

Table 6: Path-by-path comparison for gender

\begin{tabular}{|c|c|c|c|c|}
\hline \multirow{2}{*}{\multicolumn{2}{|c|}{ Unconstrained model(a) }} & $\chi^{2}$ & $d f$ & $\Delta \chi^{2}$ from revised model \\
\hline & & 243.148 & \multirow{8}{*}{114} & \\
\hline \multirow[t]{7}{*}{ Constrained paths(b) } & CTE $\rightarrow$ PU & 251.221 & & $8.073^{* *}$ \\
\hline & CTE $\rightarrow$ PEU & 251.057 & & $7.909^{* \star}$ \\
\hline & CTE $\rightarrow$ ATCU & 255.959 & & $12.811^{\star \star}$ \\
\hline & $\mathrm{PU} \rightarrow \mathrm{ATCU}$ & 243.300 & & $0.152(\mathrm{~ns})$ \\
\hline & $\mathrm{PU} \rightarrow \mathrm{BI}$ & 246.197 & & 3.049 (ns) \\
\hline & PEU $\rightarrow$ ATCU & 243.209 & & 0.061 (ns) \\
\hline & ACTU $\rightarrow$ BI & 243.288 & & 0.140 (ns) \\
\hline
\end{tabular}

a. Paths for the groups were allowed to be freely estimated.

b. The path specified was constrained to be equal across the two groups.

${ }^{*} p<.05 ;{ }^{* *} p<.01$

In order to explore the gender differences, multi-sample (sub-group) tests were carried out to verify whether significant difference existed between males and females in the strength of part coefficients. This was done by constraining each path coefficient to be equal across the two groups. Based on the $\Delta \chi^{2}$, the resulting model fit was compared to the unconstrained model. The results of the analyses of gender difference are shown in Table 6 and Figure 4. Unexpectedly, only CTE $\rightarrow$ PU, CTE $\rightarrow$ PEU, and CTE $\rightarrow$ ATCU 
were found to be significantly different. Therefore, it shows that the path coefficients for PU $\rightarrow$ ATCU, PU $\rightarrow B I, P E U \rightarrow A T C U$, and ATCU $\rightarrow$ BI did not differ between the groups. Hence, hypotheses H6a, H6b, H7b, and H8 were not supported in this study. Table 7 shows the results of the hypotheses testing.

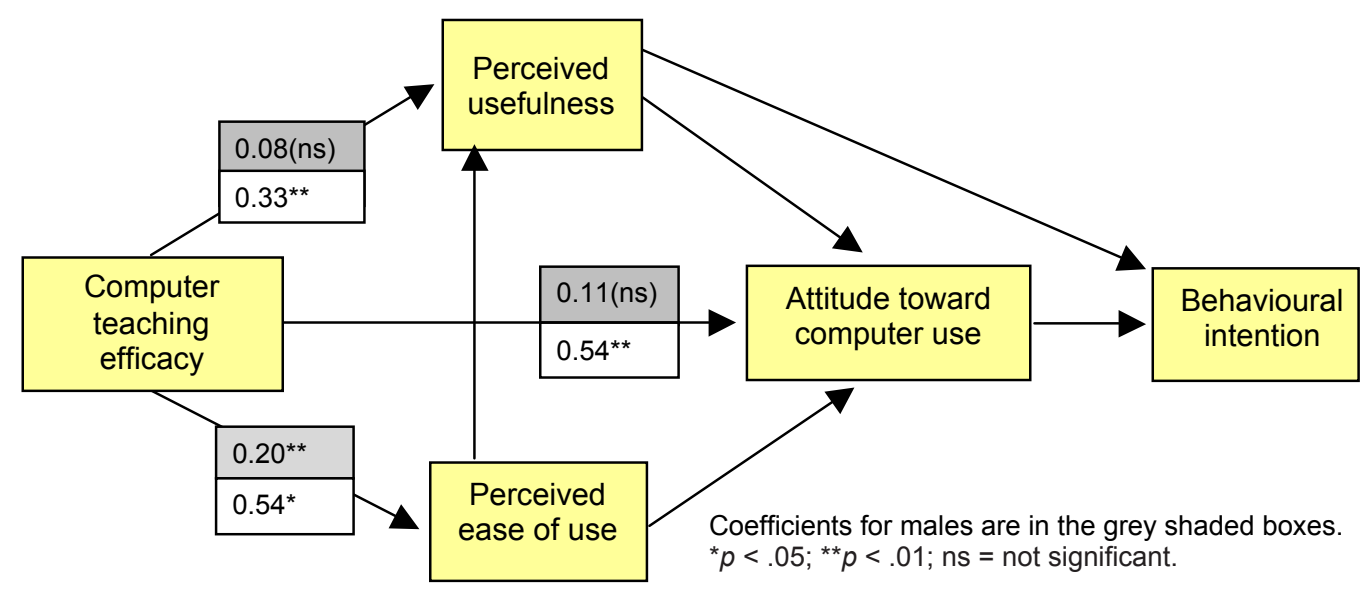

Figure 4: Significant differences standardised path coefficients for males and females

Table 7: Hypothesis testing results

\begin{tabular}{|c|c|c|c|c|}
\hline \multicolumn{2}{|c|}{ Hypotheses } & Path & Hypothesis & Results \\
\hline \multirow{8}{*}{$\begin{array}{l}\text { Main } \\
\text { effect }\end{array}$} & H1a & PU $\rightarrow$ ATCU & Positive & Supported \\
\hline & $\mathrm{H} 1 \mathrm{~b}$ & $\mathrm{PU} \rightarrow \mathrm{BI}$ & Positive & Supported \\
\hline & $\mathrm{H} 2 \mathrm{a}$ & PEU $\rightarrow$ PU & Positive & Supported \\
\hline & $\mathrm{H} 2 \mathrm{~b}$ & PEU $\rightarrow$ ATCU & Negative & Partially supported \\
\hline & $\mathrm{H} 3$ & ATCU $\rightarrow$ BI & Positive & Supported \\
\hline & $\mathrm{H} 4 \mathrm{a}$ & $\mathrm{CTE} \rightarrow \mathrm{PU}$ & Positive & Supported \\
\hline & $\mathrm{H} 4 \mathrm{~b}$ & CTE $\rightarrow$ PEU & Positive & Supported \\
\hline & $\mathrm{H} 4 \mathrm{c}$ & $\mathrm{CTE} \rightarrow \mathrm{ATCU}$ & Positive & Supported \\
\hline \multirow{7}{*}{$\begin{array}{l}\text { Gender } \\
\text { difference }\end{array}$} & H5a & $\mathrm{CTE} \rightarrow \mathrm{PU}$ & Men > Women & Not supported (women $>$ men) \\
\hline & $\mathrm{H} 5 \mathrm{~b}$ & $\mathrm{CTE} \rightarrow \mathrm{PEU}$ & Men > Women & Not Supported (women > men) \\
\hline & $\mathrm{H} 5 \mathrm{c}$ & CTE $\rightarrow$ ATCU & Men > Women & Not supported (women $>$ men) \\
\hline & H6a & PU $\rightarrow$ ATCU & Men > Women & Not supported (not different) \\
\hline & $\mathrm{H} 6 \mathrm{~b}$ & $\mathrm{PU} \rightarrow \mathrm{BI}$ & Men > Women & Not supported (not different) \\
\hline & $\mathrm{H7a}$ & PEU $\rightarrow$ ATCU & Women > Men & Not supported (not different) \\
\hline & $\mathrm{H} 8$ & $\mathrm{ACTU} \rightarrow \mathrm{BI}$ & Men $>$ Women & Not supported (not different) \\
\hline
\end{tabular}

\section{Discussion}

This study empirically validated the TAM in an educational context by going a step further to explore the role of gender and computer teaching efficacy as external variables. The findings of this research offer several important implications for the research and practice of educational technology development. Overall, the model accounted for $36.8 \%$ of the variance in behavioural intention to use computers among 
Malaysian student teachers. According to the result of goodness-of-fit test, the findings of this study led to the conclusion that the model did represent the collected data and its determinants well, towards student teachers' intention to use computers in teaching and learning.

As anticipated, perceived usefulness, perceived ease of use, and attitude toward computer use were found to have a significant positive influence on behavioural intention to use computer in teaching and learning. The findings support current research that suggests the positive and strong relationship among perceived usefulness, perceived ease of use, and attitude toward computer use towards behavioural intention (Moran et al., 2010; Pynoo et al., 2011; Rasimah et al., 2011; Teo, 2011; Sumak et al., 2011). From the effect sizes, the most dominant determinant of behavioural intention is perceived usefulness, followed by computer teaching efficacy, perceived ease of use and attitude toward computer use. Attitude toward computer use accounted for the least variance among four determinants $(\beta=.230, p<.05)$, probably due to the fact that student teachers have not seen the importance of computer engagement in their teaching activities.

With regards to specific efficacy determinants, it was also noted conclusively that computer teaching efficacy has a significant positive effect on perceived usefulness, perceived ease of use, and attitude toward computer use. Furthermore, computer teaching efficacy has the largest effect on attitude toward computer use, followed by perceived ease of use and perceived usefulness. Noteworthy is the fact that computer teaching efficacy has indirect effects on attitude toward computer use and behavioural intention to use computers. This result has provided an additional insight into the importance of computer teaching efficacy, and made a new contribution to the educational field. Due to the importance of computer teaching efficacy in stimulating higher intentions towards use of computers among student teachers, policymakers and curriculum designers should pay extra attention to increasing student teachers' belief and confidence in using computers in teaching and learning, especially in designing the curriculum for teacher educational programs. Updating the national educational technology standards in teacher educational programs from time to time is vital, as technologies continue to grow and develop rapidly. This serves as guidelines for preparing and updating courses for student teachers, towards appropriate knowledge acquisition and effective use of computers in teaching and learning, in the near future.

An unexpected interesting finding from this study is that perceived ease of use has significantly and negatively influenced student-teachers' attitude toward computer use, but the impact is very limited $(\beta=-.14, p<.05)$. This may be due to the fact that student teachers are very familiar with relatively advanced and complex computer applications such as Web 2.0, Gapminder World, Google SketchUp or SMART Notebook software and other related software. They might prefer to encounter challenges when using it for planning teaching and learning activities. This implies that the level of attitude toward computer use will decrease when individuals feel bored with the technology. This is also documented in Hong and Songan (2011), that developing countries in the Southeast Asian region are moving towards mobile technology, virtual world and cloud computing. Another plausible explanation is that this finding might have resulted from the limitations of the TAM's applicability to different user populations. The analysis showed that the majority $(89.4 \%)$ of the participating student teachers were between 21 and 23 years old and most of them frequently accessed the computer at home $(77.33 \%)$. This statistic implies that student teachers tend to have a significant degree of confidence in computer applications based on their prior 
experience in using the technology. However, further studies are required to validate it. This implies that teacher education should be reviewed and the curriculum should introduce more sophisticated software for student teachers. This will help them to face challenges of using computer for teaching and learning in the near future.

This study further investigates if any gender difference exists in the effect of the determinants on behavioural intention. Findings obtained in this study fail to verify the predictions about gender difference having moderating effects on those relationships. The findings showed that gender did not moderate the effects of PU $\rightarrow B I$, $\mathrm{PU} \rightarrow \mathrm{ATCU}, \mathrm{PEU} \rightarrow \mathrm{ATCU}$, and ACTU $\rightarrow \mathrm{BI}$. This indicates that irrespective of gender, those with higher perceived usefulness, perceived ease of use, and attitude toward computer use towards using computers had higher levels of intention to use computer than those with lower perceived usefulness, perceived ease of use, and attitude toward computer use. This result is contradictory to the previous studies which revealed that gender significantly moderated the effects of perceived usefulness and perceived ease of use towards intention to use technology (Gefen \& Straub, 1997; Venkatesh et al., 2003; Y.-S. Wang \& Shih, 2009). This may due to the fact that computers-in-education have permeated the everyday lives of pre-service teachers and differences in the use between male and female have been narrowed till it was no longer be significant (Chou, Wu, \& Chen, 2011; Teo, 2010).

However, an interesting finding from this study is that the effect of computer teaching efficacy on perceived usefulness and attitude toward computer use was significant for women, but insignificant for men. Also, computer teaching efficacy affected perceived ease of use more strongly for women rather than for men. This means that compared to men, women will be more strongly influenced by their own ability to teach with computers, and also by their belief about using computers as effective teaching methods to improve students' performance in learning. This may be due to the fact that men tend to have higher computer self-efficacy, and thus computer teaching efficacy does not influence their perceptions towards perceived usefulness and attitude toward computer use. Many studies have noted that women showed lower computer self-efficacy than men (Koch et al., 2008; Ong \& Lai, 2006; Sieverding \& Koch, 2009). The lower self-efficacy belief of women towards technologies may have consequences for their own ability beliefs in the use of computers for teaching. Specific pedagogicaltechnology courses need to be introduced for women to allow them to gain confidence, and a belief that using computers could improve students' performance. However, this justification needs further examination and evaluation, as well as a larger group of participating student teachers.

\section{Limitations and direction for future research}

It is important to state the limitations of the study to frame the above discussions and recommendations. Firstly, the population of this study was student teachers only. Therefore, the findings derived from the analyses may not reflect adequately the perceptions of in-service teachers, who are presumed to be more likely than student teachers to be exposed to demands in the use of computers for teaching and learning. Secondly, the selected determinants used in this study were not able to reflect the overall intention towards use of computers among student teachers, as the total variance accounting for behavioural intention was only $36.8 \%$, leaving $63.2 \%$ unexplained. Congruent with these findings, future research should include different types of contextual variables in the study, to account for the unexplained variance for 
intentions towards use of computers among student-teachers. As noted above, some questionnaires have been discarded, due to being only partially completed, thus future studies should consider giving more time for student teachers to fill out the survey question, maybe a week, instead of distributing and collecting the questionnaire within the final hour on the last day of lectures.

\section{References}

Ahmad, T. B. T., Basha, K. M., Marzuki, A. M., Hisham, N. A. \& Sahari, M. (2010). Faculty's acceptance of computer based technology: Cross-validation of an extended model. Australasian Journal of Educational Technology, 26(2), 268-279. http: / / www.ascilite.org.au/ajet/ajet26/ahmad.html

Ajzen, I. (1985). From intentions to actions: A theory of planned behavior. In J. Kuhl \& J. Beckmann (Eds.), Action control: From cognition to behavior (Vol. 2, pp. 11-39). http:/ / people.umass.edu/aizen/

Ajzen, I. \& Fishbein, M. (1980). Understanding attitudes and predicting social behavior. New Jersey: Prentice-Hall.

Almekhlafi, A. G. \& Almeqdadi, F. A. (2010). Teachers' perceptions of technology integration in the United Arab Emirates school classrooms. Educational Technology \& Society, 13(1), 165-175. http: / / www.ifets.info/journals/13_1/16.pdf

Bandura, A. (1977). Self-efficacy: Toward a unifying theory of behavioral change. Psychological Review, 84(2), 191-215. http:/ / dx.doi.org/10.1037/0033-295X.84.2.191

Chai, C. S., Koh, J. H. L. \& Tsai, C. C. (2010). Facilitating preservice teachers' development of technological, pedagogical, and content knowledge (TPACK). Educational Technology $\mathcal{E}$ Society, 13(4), 63-73. http:// www.ifets.info/journals/13_4/7.pdf

Chen, R. (2010). Investigating models for preservice teachers' use of technology to support student-centered learning. Computers $\mathcal{E}$ Education, 55(1), 32-42. http: / / dx.doi.org/10.1016/j.compedu.2009.11.015

Chou, C., Wu, H. C., \& Chen, C. H. (2011). Re-visiting college students' attitudes toward the Internet-based on a 6-T model: Gender and grade level difference. Computers $\mathcal{E}$ Education, 56(4), 939-947. http:/ / dx.doi.org/10.1016/j.compedu.2010.11.004

Chu, R. J. (2010). How family support and Internet self-efficacy influence the effects of e-learning among higher aged adults: Analyses of gender and age differences. Computers $\mathcal{E}$ Education, 55(1), 255-264. http: / / dx.doi.org/10.1016/j.compedu.2010.01.011

Compeau, D. R. \& Higgins, C. A. (1995). Computer self-efficacy: Development of a measure and initial test. MIS Quarterly, 19(2), 189-211. http: / / www.jstor.org/ stable/ 249688

Davis, F. D., Bagozzi, R. P. \& Warshaw, P. R. (1989). User acceptance of computer technology: A comparison of two theoretical models. Management Science, 35(8), 982-1003. http:/ / dx.doi.org/10.1287/mnsc.35.8.982

Davis, F. D. (1989). Perceived usefulness, perceived ease of use, and user acceptance of information technology. MIS Quarterly, 13(3), 319-340. http:/ / www.jstor.org/stable/249008

Gefen, D. \& Straub, D. W. (1997). Gender differences in the perception and use of e-mail: An extension to the technology acceptance model. MIS Quarterly, 21(4), 389-400. http: / / dx.doi.org/10.2307/249720

Gibson, S. \& Dembo, M. H. (1984). Teacher efficacy: A construct validation. Journal of Educational Psychology, 76(4), 569-582. http:/ / psycnet.apa.org/index.cfm?id=1985-10856-001

Hair, J. F., Black, W. C., Babin, B. J. \& Anderson, R. E. (2010). Multivariate data analysis: A global perspective (7th ed.). Upper Saddle River, New Jersey: Pearson-Hall International. 
Hayes, D. N. A. (2007). ICT and learning: Lessons from Australian classrooms. Computers $\mathcal{E}$ Education, 49(2), 385-395. http: / / dx.doi.org/10.1016/j.compedu.2005.09.003

Hong, K. S. \& Songan, P. (2011). ICT in the changing landscape of higher education in Southeast Asia. In K. S. Hong \& K. W. Lai (Eds), ICT for accessible, effective and efficient higher education: Experiences of Southeast Asia. Australasian Journal of Educational Technology, 27(Special issue, 8), 1276-1290. http: / / www.ascilite.org.au/ ajet/ ajet27/hong.html

King, W. R. \& He, J. (2006). A meta-analysis of the technology acceptance model. Information $\mathcal{E}$ Management, 43(6), 740-755. http: / / dx.doi.org/10.1016/j.im.2006.05.003

Kline, R. B. (2005). Principles and practice of structural equation modeling. New York: Guilford Press.

Koch, S., Muller, S. \& Sieverding, M. (2008). Women and computers. Effects of stereotype threat on attribution of failure. Computers $\mathcal{E}$ Education, 51(4), 1795-1803. http: / / dx.doi.org/10.1016/j.compedu.2008.05.007

MacKinnon, D. P. (2008). Introduction to statistical mediation analysis. New York: Erlbaum Press.

Moran, M., Hawkes, M., \& El Gayar, O. (2010). Tablet personal computer integration in higher education: Applying the unified theory of acceptance and use technology model to understand supporting factors. Journal of Educational Computing Research, 42(1), 79-101. http: / / dx.doi.org/10.2190/EC.42.1.d

Ong, C. S. \& Lai, J. Y. (2006). Gender differences in perceptions and relationships among dominants of e-learning acceptance. Computers in Human Behavior, 22(5), 816-829. http: / / dx.doi.org/10.1016/j.chb.2004.03.006

Pynoo, B., Devolder, P., Tondeur, J., van Braak, J., Duyck, W. \& Duyck, P. (2011). Predicting secondary school teachers' acceptance and use of a digital learning environment: A crosssectional study. Computers in Human Behavior, 27(1), 568-575. http: / / dx.doi.org/10.1016/j.chb.2010.10.005

Rasimah, C. M. Y., Ahmad, A. \& Zaman, H. B. (2011). Evaluation of user acceptance of mixed reality technology. In K. S. Hong \& K. W. Lai (Eds), ICT for accessible, effective and efficient higher education: Experiences of Southeast Asia. Australasian Journal of Educational Technology, 27(Special issue, 8), 1369-1387.

http: / / www.ascilite.org.au/ajet/ajet27/ rasimah.html

Riggs, I. M. \& Enochs, L. G. (1990). Toward the development of an elementary teacher's science teaching efficacy belief instrument. Science Education, 74(6), 625-637. http: / / dx.doi.org/10.1002/ sce.3730740605

Sang, G., Valcke, M., van Braak, J. \& Tondeur, J. (2010). Student teachers' thinking processes and ICT integration: Predictors of prospective teaching behaviors with educational technology. Computers \& Education, 54(1), 103-112. http:/ / dx.doi.org/10.1016/j.compedu.2009.07.010

Shroff, R. H., Deneen, C. C. \& Ng, E. M. W. (2011). Analysis of the technology acceptance model in examining students' behavioural intention to use an e-portfolio system. Australasian Journal of Educational Technology, 27(4), 600-618. http: / / www.ascilite.org.au/ajet/ajet27/shroff.html

Sieverding, M. \& Koch, S. C. (2009). (Self-)Evaluation of computer competence: How gender matters. Computers E Education, 52(3), 696-701. http:/ / dx.doi.org/10.1016/j.compedu.2008.11.016

Teo, T. (2010). Measuring the effect of gender on computer attitudes among pre-service teachers: A multiple indicators, multiple causes (MIMIC) modeling. Campus-Wide Information Systems, 27(4), 227-239. http:/ / dx.doi.org/10.1108/10650741011073770 
Teo, T. \& Noyes, J. (2011). An assessment of the influence of perceived enjoyment and attitude on the intention to use technology among pre-service teachers: A structural equation modeling approach. Computers $\mathcal{E}$ Education, 57(2), 1645-1653. http: / / dx.doi.org/10.1016/j.compedu.2011.03.002

Teo, T. (2009a). Examining the relationship between student teachers' self-efficacy beliefs and their intended uses of technology for teaching: A structural equation modelling approach. The Turkish Online Journal of Educational Technology, 8(4), 7-16. http: / / www.tojet.net/articles/v8i4/841.pdf

Teo, T. (2009b). Modelling technology acceptance in education: A study of pre-service teachers. Computers E Education, 52(2), 302-312. http:/ / dx.doi.org/10.1016/j.compedu.2008.08.006

Teo, T. (2011). Factors influencing teachers' intention to use technology: Model development and test. Computers $\mathcal{E}$ Education, 57(4), 2432-2440. http: / / dx.doi.org/10.1016/j.compedu.2011.06.008

Terzis, V. \& Economides, A. A. (2011). The acceptance and use of computer based assessment. Computers $\mathcal{E}$ Education, 56(4), 1032-1044. http:/ / dx.doi.org/10.1016/j.compedu.2010.11.017

Thompson, R. L., Higgins, C. A. \& Howell, J. M. (1991). Personal computing: Toward a conceptual model of utilization. MIS Quarterly, 15(1), 125-143. http:// www.jstor.org/stable/249443

Venkatesh, V. (2000). Determinants of perceived ease of use: Integrating control, intrinsic motivation, and emotion into the technology acceptance model. Information Systems Research, 11(4), 342-365. http: / / dx.doi.org/10.1287/isre.11.4.342.11872

Venkatesh, V. \& Davis, F. D. (2000). A theoretical extension of the technology acceptance model: Four longitudinal field studies. Management Science, 46(2), 186-204. http: / / dx.doi.org/10.1287/mnsc.46.2.186.11926

Venkatesh, V. \& Morris, M. G. (2000). Why don't men ever stop to ask for directions? Gender, social influence, and their role in technology acceptance and usage behavior. MIS Quarterly, 24(1), 115-139. http:/ / dx.doi.org/10.2307/3250981

Venkatesh, V., Morris, M. G., Davis, G. B. \& Davis, F. D. (2003). User acceptance of information technology: Toward a unified view. MIS Quarterly, 27(3), 425-478. http: / / www.jstor.org/ stable/30036540

Wang, H. Y. \& Wang, S.H. (2010). User acceptance of mobile Internet based on the unified theory of acceptance and use of technology: Investigating the determinants and gender differences. Social Behavior and Personality, 38(3), 415. http:/ / dx.doi.org/10.2224/sbp.2010.38.3.415

Wang, Y. S. \& Shih, Y. W. (2009). Why do people use information kiosks? A validation of the unified theory of acceptance and use of technology. Government Information Quarterly, 26(1), 158-165. http: / / dx.doi.org/10.1016/j.giq.2008.07.001

Wong, K. T., Goh, S. C., Hanafi, H. F. \& Osman, R. (2010). Computer attitudes and use among novice teachers: The moderating effects of school environment. Malaysian Journal of Learning and Instruction, 7, 93-112. http:/ / mjli.uum.edu.my/index.php/joomla-home/category /7mjli-vol.-7-2010?download $=52$

Wong, S. L. \& Teo, T. (2009). Investigating the technology acceptance among student teachers in Malaysia: An application of the technology acceptance model (TAM). The Asia Pacific Education Researcher, 18(2), 261-272.

Wozney, L., Venkatesh, V. \& Abrami, P. C. (2006). Implementing computer technologies: Teachers' perceptions and practices. Journal of Technology and Teacher Education, 14(1), 173207. http:/ / www.editlib.org/p/5437; also at http: / / doe.concordia.ca/cslp/wozneyetaljtte141.pdf 
Sumak, B., Hericko, M., Pusnik, M. \& Polancic, G. (2011). Factors affecting acceptance and use of Moodle: An empirical study based on TAM. Informatica, 35, 91-100. [verified 29 Jul 2012] http: / / www.informatica.si / PDF / 35-1/12_Sumak-Factors $\% 20$ affecting $\%$ 20acceptance $\%$ 20and $\% 20$ use $\% 20$ of $\% 20$ Moodle.pdf

\section{Appendix: Constructs and corresponding items}

\begin{tabular}{|c|c|c|c|}
\hline \multicolumn{2}{|c|}{ Item } & Statement & \multirow{4}{*}{\begin{tabular}{|l}
\multicolumn{1}{c}{ References } \\
Davis (1989); \\
Teo (2009b); \\
Venkatesh et al. (2003)
\end{tabular}} \\
\hline \multirow[t]{3}{*}{ PU } & PU1 & $\begin{array}{l}\text { I could improve my performance by using } \\
\text { computers. }\end{array}$ & \\
\hline & PU2 & $\begin{array}{l}\text { I could increase my productivity by using } \\
\text { computers. }\end{array}$ & \\
\hline & PU3 & $\begin{array}{l}\text { I could enhance my effectiveness by using } \\
\text { computers. }\end{array}$ & \\
\hline \multirow[t]{3}{*}{ PEU } & PEU1 & $\begin{array}{l}\text { It is easy for me to do works that I want to do by } \\
\text { using computers. }\end{array}$ & \multirow{3}{*}{$\begin{array}{l}\text { Davis (1989); } \\
\text { Teo (2009b); } \\
\text { Venkatesh et al. (2003) }\end{array}$} \\
\hline & PEU2 & I find computers easy to use. & \\
\hline & PEU3 & $\begin{array}{l}\text { My interaction with computers is clear and } \\
\text { understandable. }\end{array}$ & \\
\hline \multirow[t]{2}{*}{ ATCU } & ATCU1 & $\begin{array}{l}\text { Working with computers make learning more } \\
\text { interesting. }\end{array}$ & \multirow{2}{*}{$\begin{array}{l}\text { Compeau and Higgins (1995); } \\
\text { Teo (2009b); } \\
\text { Thompson et al. (1991) }\end{array}$} \\
\hline & ATCU2 & Working with computers is fun. & \\
\hline \multirow[t]{3}{*}{ CTE } & CTE1 & $\begin{array}{l}\text { I believe teaching with computer would help } \\
\text { students achieve. }\end{array}$ & \multirow[t]{3}{*}{$\begin{array}{l}\text { Gibson and Dembo (1984); } \\
\text { Riggs and Enochs (1990) }\end{array}$} \\
\hline & CTE2 & $\begin{array}{l}\text { I am very unsure of my abilities to teach with } \\
\text { computers. }\end{array}$ & \\
\hline & CTE3 & $\begin{array}{l}\text { In the future, if the performance of my students } \\
\text { improves, I believe it is usually because of } \\
\text { effective teaching with computers. }\end{array}$ & \\
\hline \multirow[t]{2}{*}{ BI } & BI1 & $\begin{array}{l}\text { Whenever possible, I intend to use computers for } \\
\text { teaching and learning. }\end{array}$ & \multirow{2}{*}{$\begin{array}{l}\text { Davis (1989); } \\
\text { Teo (2009b); } \\
\text { Venkatesh et al. (2003) }\end{array}$} \\
\hline & BI2 & $\begin{array}{l}\text { I plan to use computers during my teaching } \\
\text { practicum. }\end{array}$ & \\
\hline
\end{tabular}

Authors: Dr Kung-Teck, Wong (Corresponding author)

Sultan Idris Education University

Tanjong Malim, 35900, Perak, Malaysia

Email: thomas@fppm.upsi.edu.my Web: http:/ / www.upsi.edu.my/en/

Dr Timothy Teo, Associate Professor

University of Auckland, New Zealand

Email: t.teo@auckland.ac.nz

http: / / www.education.auckland.ac.nz/uoa/ timothy-teo

Dr Sharon Russo, Senior Lecturer

University of South Australia, Australia

Email: Sharon.Russo@unisa.edu.au

Please cite as: Wong, K. T., Teo, T. \& Russo, S. (2012). Influence of gender and computer teaching efficacy on computer acceptance among Malaysian student teachers: An extended technology acceptance model. Australasian Journal of Educational Technology, 28(7), 1190-1207. http: / / www.ascilite.org.au / ajet/ ajet28/ wong-kt.html 